\title{
Multi-Source Assessment - A Total Quality Management Driven Performance Appraisal System: The Issue of Fairness
}

\author{
ZAINI ABDULLAH \\ Institute of Knowledge Advancement (InKA) \\ Universiti Teknologi MARA \\ RUSHAMI ZIEN YUSOFF \\ Faculty of Management of Technology \\ Universiti Utara Malaysia
}

\begin{abstract}
Performance Management and Total Quality Management are important factors of organizational life. It helps organizations to identify and manage the performance of highs achievers, as well as identify low and non-performers for intervention and development. Total Quality Management takes a systemoriented perspective in managing individuals and group performance and must be compatible with continuous improvement efforts and customer-based strategies. The TQM driven Multi-source Assessment provides an alternative to traditional supervisor only appraisal process. This study was undertaken to determine whether Total Quality Management (TQM) based multi-source assessment (MSA) appraisal is perceived as fairer than traditional supervisor only appraisal system. The study was conducted using multi-group experimental design in a field setting. The perceived fairness of the performance assessment system was tested using the combined pretest posttest data of the experimental and control group. The t-test results indicated that changes in agreement scores from pretest to posttest result were significant and respondents perceived the TQM driven MSA process to be fairer. The results and discussion of the study show that the MSA process depicts a paradigm shift, not only to management process, but how employees see their changing roles in total quality management driven organization.
\end{abstract}

\begin{abstract}
ABSTRAK
Pengurusan Prestasi dan Pengurusan Kualiti Menyeluruh adalah faktor penting dalam kehidupan organisasi. Ianya membantu organisasi mengenal pasti dan mengurus prestasi mereka yang cemerlang dan juga mengenal pasti ahli-ahli organisasi yang lemah dan kurang berprestasi untuk usaha intervensi dan pembangunan. Pengurusan Kualiti Menyeluruh menggunakan perspektifyang berorentasikan sistem dalam pengurusan prestasi individu dan pasukan bagi memastikan ianya selaras dengan usaha yang berterusan dan strategi berpaksikan pelanggan. Penilaian Pelbagai Sumber (Multi-Source Assessment) yang berpaksikan Pengurusan Kualiti Menyeluruh memberikan alternatif kepada proses penilaian tradisional yang berpaksikan proses penilaian daripada ketua. Kajian ini dilaksanakan untuk menilai sejauh manakah Sistem Penilaian Pelbagai Sumber yang berorentasikan Pengurusan Kualiti Menyeluruh dianggap lebih adil daripada sistem penilaian tradisional. Kajian yang dijalankan menggunakan reka bentuk eksperimen pelbagai kumpulan. Tanggapan keadilan sistem penilaian prestasi diuji menggunakan gabungan data pra ujian dan pasca ujian daripada kumpulan kawalan dan kumpulan eksperimen. Ujian-t menunjukkan keputusan yang signifikan di mana responden mendapati Penilaian Pelbagai
\end{abstract}


Sumber (MSA) lebih adil daripada penilaian tradisional (SSA). Hasil kajian juga menunjukkan proses MSA memperlihatkan perubahan paradigma, bukan sahaja kepada proses pengurusan, begitu juga bagaimana ahli organisasi melihat perubahan peranan mereka dalam organisasi yang berorientasikan pengurusan kualiti menyeluruh.

\section{INTRODUCTION}

Performance appraisal is the key to effective human resources management. Latham and Wexley, (1982) identified selection, appraisal, training and motivation as the four key systems necessary for ensuring the proper management of an organization's human resources. Of these four, they argue that performance appraisal is the most important because it is the prerequisite for establishing the other three. The salience of an effective performance appraisal system as a tool to enhance human productivity is well documented (Glueck, 1978). Appraisal system is a critical function in organizations because they enhance productivity by targeting individual developments needs and at the same time, identifying high, medium and low performers (Bernardin \& Betty, 1984; Latham \& Wexley, 1982; and Henderson, 1989).

Organizational Challenges in Today's Environment - Its Effects on Performance Appraisal

A number of changes are taking place in many organizations, be it public or private. These largescale organizational changes are causing many rules to be re-evaluated (Mohrman, Mohrman, Ledford, Cummings \& Lawler, 1988), a re-evaluation which raises questions about the performance appraisal process. Changes driving the organizations include both environmental and cultural. Changes in the environment, such as fast changing technology, development of self-directed teams and the incorporation of customer satisfaction as the organizational objective, reflect a more rapid change in society

\section{Technological Impact}

The impact of changing technology has an effect both on employees' access to information and on their ability to manage large amounts of data. Contemporary workers often have extensive knowledge or access to technology-based information. These knowledgeable workers may over- see day-to-day responsibilities, and be involved in managerial decision-making. This access to information has changed the power relationship within the organization.

\section{Self-Directed Teams}

The increasing use of self-directed work teams drives new adaptive responses (Mohrman, Mohrman \& Lawler, 1987). Self-directed work teams provide a new model for getting work accomplished. The self-directed work team developed from quality initiatives, fosters employees' participation. Performance assessment becomes a critical factor for the self-directed team. Performance measures are needed to identify the degree to which the team is meeting its goals and objectives, and who within the team is and is not contributing to the success. These changes require new approaches to the traditional performance appraisal process, which relies on the supervisor alone to make the performance assessment.

\section{Customer Satisfaction as Organizational Objective}

In meeting the challenges faced in this customeroriented era, many organizations adapt their strategies so as to ensure that they can deliver the needs and wants of their customers. Customer focus is the corner stone of the principle of quality. These organizations use customer satisfaction to drive their business (Stephen \& Weimerskirch, 1998). Quality management system such as ISO 9000 has made a significant change in their concept by including customer satisfaction analysis as one of the main drivers of the system.

\section{Shortcomings of the Current Appraisals}

There is widespread dissatisfaction with most of the appraisal system currently used. Most of it focuses on the single-source (supervisor only) appraisal process. Substantial research indicates that traditional performance appraisal does not augur well with current organizational settings. 
The issues of bias and practicality are of greater interest to this discussion. The traditional performance appraisal process is subjective and biased (Latham \& Wexley, 1994). Other notable flaws are the vagueness of standards, subjectivity of rater and inconsistency among appraisers, that is, from one supervisor to another (Basnigth \& Wolkinson, 1977).

\section{Total Quality Management and Human Resource Performance Appraisal System}

The total quality approach is changing the role of human resource management by changing the expectation of stakeholders, within and outside the organization, with regards to human resource responsibilities. Today the objectives of total quality human resource approach are to increase customer satisfaction, both internal and external, through improved quality and to develop a more flexible, loyal and innovative work environment. Improvement in internal efficiencies is imperative to ensure organizational effectiveness and the practice of quality human resource management techniques can enhance internal efficiency (Gunasekaran, Korukonda, Virtanen, \& Yli-Olli, 1994) and competitiveness (Petrick \& Quinn, 1997). Performance assessment of the employees can be reflected in the performance measurement system that help to monitor and maintain organizational control. This is a process of ensuring that organizational resources e.g. human resource can pursue strategies that can lead to the achievement of overall goals and objectives (Nani, 1987).

Total Quality Management (TQM) means that the organization's culture is defined by and supports the constant attainment of internal customer satisfaction through an integrated system of tools, techniques and training. This involves the continuous improvement of organizational process resulting in quality 'products' and services (Sashkin \& Kaiser, 1993).

Organization invests considerable resources while implementing TQM and it will be beneficial to quantify the derived benefits in terms of improved effectiveness and competitiveness so that resource utilization can be improved. Total quality will remain a strategic issue in managing human resource for ensuring competitiveness in the knowledge economy characterized by intense competition and a continually increasing demand for a better management system.

Deming, (1986) proposed a "theory of profound knowledge". A key aspect of this theory is that the success of quality management efforts depends on effective integration of various management sub-systems. The maximum effectiveness of TQM driven Performance Management System may hinge on whether performance management sub systems are integrated and supportive of each other. In the pursuit of effectiveness, one sub system cannot be optimized at the expense of another.

TQM proponents are quick to criticize performance appraisal practices, which are based on the assumption that the individual employee is largely in control of his or her own performance level (Deming, 1986; Scholtes, 1987; and Walton, 1990). An individual based focus has been the primary paradigm used by researchers in the area of performance management. This includes an emphasis on individual performance appraisal, goal setting and feedback. Performance appraisal has been a subject of much interest to HRM researchers. Most of this effort has been devoted to characteristics of instruments and raters, with underlying goals to eliminate errors of bias, better understanding of performance-related information-processing, and ultimately to improve rating accuracy.

Research on performance management has included other individually focused phenomena that may occur before, during and after appraisal. These include planning processes and interventions designed to maintain and improve performance. For example, individual feedback and goal setting have both received much acclaim as effective ways to manage tasks performance (Ashford \& Cummings, 1983).

Characteristics that include the specificity of feedback, and the extent to which it includes both behaviors and outcomes, and the degree of difficulty to achieve goals have been associated with high performance (Chokar \& Wallin, 1984; and Locke, Shaw, Saari \& Latham, 1981). The interconnectedness of goal setting and feedback has also been discussed. Tolchinsky and King, (1980) and Bandura and Corvone, (1983) proposed that the effect of feedback depends on 
the beliefs that such feedback generates the goals that are set in response to the feedback.

Another problem associated with an individually based approach is the assumption that by enhancing individual task performance, the performance of the greater unit or organization will be enhanced. TQM proponents have been critical of the use of such individualized goal-setting practices as management by objectives for two reasons. Firstly, individuals may attempt to set or negotiate less challenging or easy to achieve goals. Secondly and perhaps more importantly from a TQM perspective, goals tend to be stressing on short-term outcomes. As noted by Deming, (1986) the traditional appraisal system will reward people who do well "within the system" but do little in an attempt to improve the system. These are potentially growing problem in the organization particularly in effectively managing performance of human resources "humanly fair".

Dobbins (1991) argued that "performance management activities would be much more fruitful if directed at system". A system-oriented approach would be primarily oriented towards improving processes, which affects the performance of all the individuals within the system. For example in performance appraisal exercise, the work flow or technical process need to be evaluated and then improved in such a way as to enhance the effectiveness and fairness of the evaluation process.

Oakland, (1993) suggested that appropriate performance measurement plays important roles in quality and productivity improvements. These are to include ensuring that customers requirements are being met; providing standards for establishing comparison, and providing visibilities and "score board" for people to monitor their own performance levels. The measurement should highlight quality problems and determine areas requiring prior attention. It should also provide feedback for driving improvement effort. For any performance appraisal system to be Total Quality Management (TQM) based it must be aligned to Total Quality Management (TQM) principles. Knouse (1996) and Stephen and Weimerskirch (1998) suggested that human resource system in general and specifically performance appraisal and compensation system should be customer driven, team oriented, based on observable and measurable behaviors and results, encourage full employee participation, include timely feedback and enhance continuous improvements.

\section{The Multi-Source Assessment (MSA) Model -A TQM based Appraisal System}

Multi-source Assessment model, a relatively new appraisal method, recommends that performance information come from multiple individuals who interact with the assessment receiver (Lawler, $1967 \&$ Bernardin, 1986). The multi-source model which is a resemblance of the 360 degrees feedback model, may include the supervisor's assessment plus that other work associates. These work associates may be colleagues, associates, peers, direct reports, the second level supervisor, and internal and external customers. This fits well with the team oriented and customer driven TQM principles discussed earlier.

Multi-source assessment introduces an important concept to the process of performance assessment. It is highly regarded that individual should be assessed by work associates with whom they interact frequently. This approach combines information from several sources that leads to "more valid and reliable performance appraisal" of individual performance (Baruch \& Harel, 1993).

Issues of reliability and validity are critical to any performance appraisal model. Performance appraisal systems that rely solely on supervisor evaluations assume that supervisor is able to observe closely their employees' behavior. The characteristic change of MSA is that it expands the evaluation team beyond the immediate supervisor, to include others such as peers, direct reports, internal and external clients and a self-appraisal. A key concern of the traditional singlesource appraisal model is that it is biased because it relies on a single perspective to provide the assessment.

In today's organization, where employees may have considerable autonomy, the assumption that supervisors may have large spans of control may not hold true. Using different viewpoints provides a more comprehensive picture of individual performance (London \& Beatty, 1993). The MSA process compensates for the limited perspec- 
tive of the supervisor by expanding the evaluation team to include those in the performer's circle of influence. Adding additional raters obviously can help improve the reliability and validity of the ratings. The MSA process represents not just an incremental change to the performance appraisal process but one that also fundamentally alters the power dimension of performance assessment by soliciting input from multiple levels of the organization.

The MSA process focuses on organizational culture and its human processes on how human intact. This is consistent with the organizational development interventions, described as facilitating an effective transformation of behaviors. This transformation requires

\begin{abstract}
Developing skills for inducing effective and satisfying interpersonal and inter-group relationships at work; increasing competencies to induce and sustain desired and desirable organizational climates; augmenting skills in conflict resolution; enhancing skills and attitudes to satisfying and productive choice or change; and enforcing specific counter-bureaucratic attitudes and behaviors, for example those related to risk-taking, openness and so on (Golembiewski, 1985).
\end{abstract}

The organizational culture and human process focus of MSA thus aligned well with TQM principles that any appraisal system must be based on observable and measurable behaviors and results (Knouse, 1996; and Stephen \& Weimerskirch 1998)

\section{OBJECTIVE OF THE STUDY}

The MSA process provides several unique characteristics to the performance appraisal process. The most significant change is the expansion of the performance evaluation team. This major change provides the basis for the hypotheses being tested in this study. The overall thesis is that by expanding the evaluation team from one person (the supervisor) to a team of co-workers with whom the appraise interacts, it is expected that the fairness of the appraisal, both perceptually and empirically, will increase.

Perceived fairness of performance appraisals may be based upon a number of factors; organizational trust, input, methods of data collection, rater training, reliability and anonymity. A key factor is, the knowledge the rater has of the individual being assessed. It is proposed that expanding the evaluation team from one perspective to multiple perspectives, and with those perspectives including people of different status in relation to the subject, will be perceived as providing a fairer appraisal rating by the appraise. Multi-source assessment appraisal process is expected to be perceived as fairer than supervisor only appraisals because the evaluation team is made up of individuals with high degree of knowledge of the appraisee's performance.

Based on the above background, the study was carried out with the objective of investigating and confirming empirically whether the Multi-Source Assessment (MSA) is perceived to be fairer than the Single-Source Assessment (SSA)

\section{Research Hypothesis}

The hypothesis for this study are as follows:

Hypothesis 1: The TQM based Multi-source appraisal (MSA) is perceived to be fairer than traditional supervisoronly performance appraisals (SSA).

Based on the literature of fairness, the study investigate the issue of fairness from the following dimensions:

- Comprehensiveness of the assessment

- Accuracy of assessment on performance

- Ability to provide effective feedback to appraisee

- Perceived to improve performance of the appraisee

- Ability to provide more confidence in the assessment feedback

- Ability to provide more safeguards

In investigating the issue of fairness from the above dimensions, the study established the following sub-hypothesis: 
Hypothesis 1a: TQM based Multi-source appraisal (MSA) is a more comprehensive assessment than the traditional Single-Source Appraisal (SSA).

Hypothesis 1b: TQM based Multi-source appraisal (MSA) process is perceived to be a more accurate assessment of performance than the traditional Single-Source Appraisal (SSA)

Hypothesis 1c: TQM based Multi-Source Appraisal (MSA) assessment is perceived to provide a more effective feedback to the appraisee than the traditional Single-Source Appraisal (SSA).

Hypothesis 1d: TQM driven Multi-Source Appraisal (MSA) outcome is perceived to improve performance of the appraisee more than traditional Single-Source Appraisal (SSA).

Hypothesis 1e: TQM based Multi-Source Appraisal (MSA) is perceived to provide more confidence in the assessment feedback than the traditional single-source appraisal (SSA).

Hypothesis 1f: The TQM - Multi-source Assessment is perceived to provide more safeguards than the traditional single-source appraisal (SSA).

\section{METHODOLOGY}

This study's research design is an experimental test of the Single-Source Appraisal model and Multi-Source Appraisal model for performance appraisal. The experimental research design is based on the modified version of the Four Group Design established by Solomon (1949) and prominently employed by Campbell and Stanley (1963) in a simillar experimental setting. The empirical data has been gathered from a Multi-Source Appraisal research project implemented at a public institution of learning. The primary test is regarding appraisee perceptions of fairness. This involved the use of pre- and post-experiment (treatment) survey to collect information from appraisee on their perception of fairness on the evaluation exercises.

The research design has been modified to address the need to compare issues of fairness between the three groups and the types of appraisal system used. This modified version of the Multiple- Group Experimental Design has the following structure:

$\begin{array}{lll}\text { O1 } & \text { X1 } & \text { O2 } \\ \text { O1 } & \text { X2 } & \\ & \text { X3 } & \text { O2 }\end{array}$

Whereas X1 represent experiment group I (pre and post treatment) using single-source and multisource appraisal, X2 represent control group (pre treatment) using the existing single source appraisal method and $\mathrm{X} 3$ represent experiment group II (post treatment) using the multi-source appraisal assessment. Os are the observations of the dependent variables, where $\mathrm{O} 1$ using single source performance appraisal and $\mathrm{O} 2$ using multi-source appraisal.

The population for the study included all the ninety-eight academic staff of one of the Technical school in Perlis, Malaysia. After discounting those who were involved in the focus group discussions for the development of the instruments for the study and those involved in the pilot test, fifty of the academic staff were taken to be the sample for this experiment. The pre-treatment survey was given to participants after completion of their traditional supervisor-only assessment regarding their perceived level of fairness of the process and the resultant rating. After the implementation of the Multi-Source Assessment, posttreatment surveys were conducted to assess the perceived level of fairness of the Multi-Source Assessment process. The ratings of perceptual fairness from the pre- and post- test instruments (SSA and MSA) on each response groups were compared using t-test. t-test was also used to test all other related sub-hypothesis. 
The Performance Evaluation Format: The SingleSource Appraisal vs. the Multi-Source Appraisal Forms

Performance evaluation format based on SSA and MSA were developed to measure the work performance of the appraisee. These performance evaluation formats were developed through a focus group discussion and interviews with the officers from the State Education Department, school teachers and higher institutions lecturers. Altogether four evaluation formats were developed and used. There are as follows:

1. Single Source Appraisal format (based on existing PSD's format)

2. Multi-Source Appraisal format for Superior appraisal

3. Multi-Source Appraisal format for Peer appraisal

4. Multi-Source Appraisal format for Students (customers) appraisal

\section{The Research Instrument}

The research questionnaire on the perception of fairness in the performance assessment was designed to answer the research questions of this study. It contained statements and questions aimed at tapping the aspects of general demographic background information on respondent and degree of perceptual fairness on SSA vs. MSA appraisal system was based on:

- The level of comprehensiveness in the performance appraisal system

- The effectiveness of the appraisal system

- The level of the performance appraisal outcomes and achievements

- The process and procedures of evaluation Confidence in the appraisal scores

- Provision for safeguards against biasness and discriminatory practices

The Pre-Experiment (Treatment) Survey Questionnaire

The purpose of this questionnaire is to measure the degree of perceptual fairness of the SingleSource Appraisal process as a performance assess- ment measure. The single-source appraisal approach is identical to the commonly practiced performance assessment method used in the public service employment. Perceptual fairness of an individual can be represented by three main approaches - outcome, procedure and system. Outcomes (rewards or punishment) come about due to performance ratings. The procedure is the manner and method by which the decisions on outcomes are made. The system defines the organizational context in which the procedure operates. The system both influences the outcome and procedure.

The elements of the perceptual fairness in the survey have been operationalized into a set of feedback response statements. The perceptual fairness statements can be categorized into the following constructs: system and structural attributes, instrument or task process profile and achievements/outcomes factors. The system and structural attributes dimension discusses the perception of fairness from the organizational context in which the procedures operates. The Hage and Aiken Formalization Inventory (based on Miller, 1991) was adapted to formulate statements for this dimension. In this context perceptual fairness was measured by the comprehensiveness and effectiveness of the appraisal system.

The instrument or task process profiles describe the procedures and processes in evaluating employees fairly. Procedural justice (fairness) represents the processes for ensuring fairness, or equity in appraising performance (Sheppard, Lewicki \& Minton, 1992). Significant research has argued that the "perception of procedural fairness is at least as important as perception of outcomes of fairness" (Lind \& Tyler.1988). The achievements or outcomes factors are key components to perceptual fairness in any evaluation system. The outcomes may be extrinsic in nature such as rewards, promotion or for purpose of training or recognition. Distributive justice (fairness) articulates the equity perspective of fairness. People expect to receive rewards that commensurate their efforts. Perceptual fairness has been closely linked to performance and productivity (Sashkin \& Williams, 1990). 


\section{The Post-Experiment (Treatment) Survey Questionnaire}

This post-test questionnaire is designed to measure the degree of perceptual fairness of the MultiSource Appraisal process. The multi-source appraisal approach is not a commonly practiced performance assessment method in the public sector. Again, the measure of perceptual fairness of an individual can be represented by the three main approaches - outcome, procedure and system - as described earlier.

\section{Validity and Reliability of the Research Instru-} ments

The content validity of all the research instruments used in the study were established through focused group discussions comprising experts from a broad spectrum. The reliability coefficients of the scales used in the study are given in Table 1 . The coefficient of the alphas of the scales used in the study ranged from 0.8489 to 0.9356 ; none of the coefficient was below 0.7 . The reliability coefficients of the research constructs for comprehensive assessment system, effective assessment system, process and procedures and achievements and outcomes were $0.9394,0.9446,0.8877,0.9525$ respectively.

Table 1:

Reliabilities of Scales Used (Alpha Coefficients) (Pretest data)

\begin{tabular}{lcc} 
Scales & No. of items & Alpha Coefficient \\
\hline Comprehensiveness & 8 & .9403 \\
Accuracy on performance & 8 & .9451 \\
Effective feedback to appraisee & 8 & .8877 \\
Outcome on performance &, 10 & .9534 \\
\hline
\end{tabular}

Similar lines of questions (statements) will be posed with emphasis on the Multi-Source Appraisal. Summation of all the questions (statements) on the various dimensions for all appraisees are categorized as follows: system and structural attributes, instrument or task process profiles and the achievements and outcomes factors.

\section{RESULTS AND ANALYSIS}

This section focuses on the data analysis of the performance ratings. All employees (teachers) were required to participate in the research process that involved the Single Source and MultiSource Assessment

\section{Findings}

This section presents the results of the seven groups of hypothesis consisting of one primary and six sub-hypothesis. These hypothesis were tested based on participants' responses to performance assessment method, effectiveness of the assessment; procedures and process of assessment, and the achievements of the appraisal approach.

\section{Summary of Research Hypothesis Results}

The primary hypothesis agrees that the MultiSource Assessment (MSA) approach provides a fairer method of assessment than the traditional Supervisor-only (SSA) performance assessment as perceived by appraisees.

- Sub hypothesis (1a) agrees that the multisource assessment is perceived as fairer because it represents a more comprehensive (complete) assessment of the performance than the single source assessment.

- Sub hypothesis (1b) agrees that the multisource assessment is perceived as more effective because it represents a more accurate assessment of the performance than the single source assessment.

- Sub hypothesis (1c) agrees that the feedback 
evaluation from the evaluating team, including co-workers and internal customers (students), will be perceived to be more effective to the appraisee than feedback only from the supervisor.

- Sub hypothesis (1d) agrees that the multisource assessment outcome is perceived to improve performance of the appraisee more than traditional source single source assessment.
- Sub hypothesis (1e) agrees that Individual appraisees have more confidence in the multisource assessment than the traditional singlesource assessment.

- Sub hypothesis (1f) agrees- that the multisource assessment will be viewed by appraisees as providing more safeguards than the traditional single-source appraisal process.

Table 2 :

SSA and MSA Survey Comparison

\begin{tabular}{lcccccccc}
\hline Construct & $\begin{array}{c}\text { Hypothesis } \\
\text { and Sub- } \\
\text { hypothesis }\end{array}$ & $\begin{array}{c}\text { Mean } \\
\text { dev }\end{array}$ & SSA & $\begin{array}{c}\text { Std. } \\
\text { Median }\end{array}$ & $\begin{array}{c}\text { Mean } \\
\text { dev }\end{array}$ & $\begin{array}{c}\text { MSA } \\
\text { Median }\end{array}$ & Std. & t-test- \\
\hline Perceived fairness & 1 & 2.35 & 2.5 & .50 & 2.97 & 3.0 & .05 & $.0 .001^{* *}$ \\
Comprehensiveness & $1 \mathrm{a}$ & 2.37 & 2.5 & .63 & 3.0 & 3.0 & 0 & $.0 .05^{*}$ \\
Accurate assessment on performance & $1 \mathrm{~b}$ & 2.47 & 2.75 & .57 & 3.0 & 3.0 & 0 & $.0 .05^{*}$ \\
Effective feedback to appraisee & $1 \mathrm{c}$ & 2.25 & 2.07 & .45 & 2.9 & 3.0 & .19 & $.0 .001^{* *}$ \\
Outcome on performance & $1 \mathrm{~d}$ & 2.32 & 2.25 & .61 & 2.9 & 3.0 & .03 & $.0 .001^{* *}$ \\
Provide confidence & $1 \mathrm{e}$ & 2.7 & 3.0 & .48 & 3.0 & 3.0 & 0 & $.0 .001^{* *}$ \\
Provides safeguards & $1 \mathrm{f}$ & 2.1 & 2.0 & .87 & 3.0 & 3.0 & 0 & $.0 .05^{*}$ \\
\hline
\end{tabular}

* significant at $p<.05$ level

$* *$ significant at $\mathrm{p}<.001$ level

\section{DISCUSSION}

The results of this study show that a change in how performance management is undertaken has an effect on user perception of performance appraisal fairness in organizations. Multi-source assessment appears to provide a tool that fosters perceived fairness in the performance assessment feedback process. It overcomes the issues of biasness and subjectivity that are inherent in the traditional single source performance appraisal process as pointed out by Latham and Wexley (1994). It also manages to solve the problems that are related to the vagueness of standards, subjectivity of rater and inconsistency among appraisers that are present in the single source appraisal process as reported by Basnigth and Wolkinson (1977). The process may increase the level of trust where the system is treating individuals fairly. This ultimately would also provide greater satisfaction to the employees and supervisors. Therefore, multi-source assessment process can facilitate organization's response to the dramatic changes in the workforce and the environment.

For many employees, the introduction of co-workers or peers to the rating process enhanced the perspective of performance. It was recognized by employees that supervisors could not provide a comprehensive review of performance. This could be due to their broadened job responsibility, lower levels of technical skills, or remote reporting situation. The addition of co-workers broadens the perspective of performance, leading the individual to view performance rating as more comprehensive and complete. This corroborates with Kaplan's (1993) reiteration that co-workers should be treated as internal customers and therefore they can provide useful feedback to enhance 
workers performance. The MSA process that includes peer evaluation therefore will broaden the perspective of performance measurement. The evaluation team consists of members of the knowledge network around the individual performers, e.g. co-workers, who have greater knowledge of the job performance than the supervisor or rater. These co-workers may spend more time either in work or non-work settings, plus more likely to have similar technical information that is relevant to the task or job done. For this reason, co-workers feedback becomes more motivational because it is more credible and reliable, coming from a source that is "on site" and more aware of the job responsibility. This agrees with Cummings and Schwab's (1973) and Baruch and Harel's (1993) views that peer appraisal is a reliable and valid source of performance measures as ratings of peers which show a correlation with work performance.

The process gives appraisees confidence in the results. Organizational trust is fostered through competency and participation. The Multisource assessment process focuses on specific behavioral competencies identified as relevant to the organization's specific responsibility. As argued by Dobbins (1991), the focus on competencies is important, as it will enhance the usefulness of the appraisal process in improving workers performance. Employee participation enhances confidence in the overall process; the involvement of the individual's co-workers in providing performance evaluation, enhances confidence, or trust, in the ratings results that the appraisal process provides. This is in aggreement with Schneir (1977), that MSA process is highly participatory because it uses multi-rater and increases participation beyond the supervisors in the performance appraisal process. This MSA approach is consistent with the high involvement oriented management practises.

The process provides safeguards that are not a feature of the single-source supervisory assessment. Multi-source assessment provides additional options with regards to the design mechanism of the assessment system that provide safeguards to the process. The ability to organize and track raters and indicate degree of inter-rater agree- ment is an enhancement to ensuring a fairer approach to performance assessment. This concurs with London and Beatty's (1993) findings that MSA incorporates safeguards to fairness and therefore enhances participation and confidence in accuracy of the feedback receivers. This is not a characteristic or even feasible within the format of the single source appraisal system. Providing anonymity to feedback providers or raters is necessary for assessing co-workers to identify individual or ratee strengths and weaknesses. Without this safeguard, evaluators may not be willing to identify and discuss weaknesses. This would undermine the Multi-source assessment process by neutralizing the feedback and creating undifferentiated reports such as that provided by the single-source appraisal method.

Rater tracking is made available in the Multi-source assessment processes which ensure rater anonymity. Rater anonymity must be sustained to ensure perceived fairness of the MSA process. London and Beatty (1993) indicated that anonymity is fundamental to a fair appraisal process and this is supported by their research findings. However, rater tracking relies on the usage of a software program that can balance the desire for anonymous ratings while protecting appraisees or ratees from personal attacks or retaliations. If the number of raters is too small and it is virtually impossible to remain anonymous, the peer assessment (as assigned) could be justified as an official system of the assessment process just as the single supervisor assessment.

Many supervisors perceived the Multisource assessment process as supporting their ongoing responsibility to provide performance assessment by giving them information beyond the normal range to which they had access. Multisource assessment enhances their roles as coaches and developers. This support the views pointed out by Latham and Wexley (1982), that MSA process moves supervisor from the role of judge to the role of coach. Through the Multi-source assessment mechanism, they have total responsibilities for providing a comprehensive and accurate appraisal. Information was provided to help them facilitate employees' development. 


\section{CONCLUSION}

Performance management is a necessary and important process in organizational life but it has not worked as well as the theory suggests. Many organizations have changed so radically in recent years, requiring mechanism to respond to customers, stakeholders, and employee requirements. TQM initiatives are underway in many public sector organizations. These initiatives present additional opportunities to the performance management process regarding employee involvement, open communication and "driving out of fear". While the orientation in public organization must continue to focus on efficient and effective delivery of services, other considerations must also be addressed.

This research tested an Multi-source assessment process as a model for performance assessment that addresses multiple areas of concern. The results of this research may change how quality driven performance management is undertaken in the future for organizations. The Multi-source assessment process provides a new approach leading to a fairer system of performance assessment ratings. It gives higher quality information than just the single-source appraisal system. It is more specific and viewed as being fairer and more accurate as it provides a more comprehensive perspective of performance. Consequently, the motivational impact on the assessment is higher than the traditional single-source appraisal process. The multi-source assessment fosters continuous improvement in performance by enhancing communication and improving cooperation and increasing the level of confidence and trust.

The Multi-source assessment process evaluated in this research indicates that it adds value to the performance appraisal process. Participants evaluated the process as being fairer than the previous assessment process, the single-source assessment. Additionally, employees who often experience an "unfair" assessment results rated the new assessment process Multi-source assessment (MSA) as significantly fairer.

The issue of fairness is critical to public organizations. The focus on providing efficient and effective services continues to be a basic value and driving force of the public sector departments.
The focus of this research on fairness asserts that employees' rights are also important. Fairness is a fundamental value inherent in the structure of the democratic process. Fairness is a critical variable in supporting the performance assessment process in organizations. Enhancing employees' beliefs that the performance assessment process is fair serves all parties - the organization, the individual and the public served.

This research demonstrates an alternative approach for public sector agencies like the school system to meet the challenge of changing organizational realities, including employee and client expectations. The call to bring about changes in government's rigid mechanism of performance ratings and assessment requires significant changes to how government employees are evaluated on their performance. Allowing the employee to develop performance assessment criteria that is tied to the organization's mission and values provides a compelling mission on performance expectations. Expanding the evaluation team from the traditional supervisor's appraisal only, to a group of co-workers and related clients, who see the employee in a variety of settings and more frequently, strengthens the performance assessment process.

It is envisioned that this research will provide a benchmark model for multi-source assessment appraisals. This study will assist the Public Services Department of Malaysia in developing and implementing a performance assessment process in line with the Malaysian Remuneration System of managing public sector performance management system. This research also provides a process for organizations to foster employees' involvement in the TQM initiatives. It provides an insight for organizations to use Total Quality Management (TQM) driven performance assessment approach that is viewed as a more comprehensive, accurate and fairer process than the single- source model.

\section{REFERENCES}

Ashford, S. J., \& Cummings, L. L. (1983). Feedback as an individual resource: Personal strategies of creating information. Or- 
ganization Behavior and Human Performance. 32, 370-398.

Bandura, A., \& Carvone, D. (1983). Self-evalu ation and self-efficacy mechanism governing the motivational effects of goal system. Journal of Personality and Social Psychology. 45, (5), 1017-1025.

Baruch, Y., \& Harel, G. (1993). Multi-source performance appraisal: An empirical, and methodological note. PAQ, 17, (1), 96-111.

Basnigth, T. A., \& Benjamin W. W. (1977). Evaluating managerial performance: Is your appraisal system legal? Employee Relations Law Journal. 3, 240-54.

Bernardin, H. J. (1986). Subordinate appraisal: A valuable source of information about managers. Human Resource Management, 25, 421-39.

Bernardin, H. J., \& R. W. Beatty. (1984). Performance appraisal: Assessing human behavior at work. Boston: Kent.

Campbell, D. T., \& Stanley, J. C. (1963). Experimental and Quasi Experimental Design for research. Chicago: Rand- Mc Nally.

Chokar, J. S., \& Wallin, J. A. (1984). Improving safety through applied behavioral

analysis. Journal of Safety Research. 15, (4), 141151.

Cummings, L., \& Shcwab, D. (1973). Performance in organizations. Chicago: Scott, Foresman.

Deming, W. E (1986). Out of the crisis. Cambridge: MIT Center for Advanced Engineering Study.

Dobbins, G. H., Cardy, R. L., \& Carson, K. P. (1991). Examining fundamental assumptions: A contrast of person and sys- tem approaches to human resources management. In G. Ferris, Ed. Research in personnel and human resource management. 4, 2-20.

Glueck, W. F. (1978). Personnel- A diagnostic approach. Dallas, TX: Business Publications, Inc.

Golembiewski, R. T. (1985). Humanizing public organizations. Mt. Airy, MD: Lomand.

Gunasekaran, A., Korukonda, A. R., Virtanen, I., \& Yli-Olli, P. (1994), Improving productivity and quality in manufacturing organizations. International Journal of Production Economics. 36, (2),169-183.

Henderson, J. D. (1989). Private sector management: Promoting efficiency, and costeffectiveness. Corrections Today. 12, (October), 98-102.

Kaplan, R. E. (1993). 360-degree feedback plus: boosting the power of co-worker ratings for executives. Human Resource Management, 32, (2), 299-314.

Knouse, S. B. (1996). Human resources management perspectives on TQM: Concepts a practices. Milwaukee: ASQC Quality Press.

Latham, G. P., \& Kenneth, N. W. (1982, rev. 1994.) Increasing productivity through performance appraisal. Reading, M.A: AddisonWesley.

Latham, G. P., \& Kenneth N. W. (1982, rev. 1994). Increasing productivity through performance appraisal. Reading, MA: AddisonWesley.

Lawler, E. E., III. (1967). The multirait-multitraiter approach to measuring managerial job performance. Journal of Applied Psychology. 51, (2), 369-81. 
Lind, E. A., \& Tyler, T. (1988). The social psychology of procedural justice. New York: Plenum.

Locke, E. A., Shaw, K. N., Saari, L. M., \& Latham G. P. (1981). Goal setting in task

performance: 1969-1980. Psychological Bulletin. 90, 125-152.

London, M. \& Beatty, R.W. (1993). 360-degree feedback as a competitive advantage. Human Resource Management. 32, 35372.

Miller, C. D. (1991). Handbook on research design and social measurement. Newbury Park, California: Saga Publication.

Mohrman, A. M., Jr., Susan A. M., \& Edward E. L. III. (1987). The performance management of teams. CEO Publication. G912, 187.

Mohrman, A. M., Jr., Susan A. M., Gerald E. L. Jr., Thomas G. C., \& Edward E. L. III, and Associates. (1988). Large-scale organizational change. San Francisco: Jossey-Bass.

Nani, L. R. (Nov, 1987). Corporations as persons: Objections to goodpaster's 'principle of moral projection. Journal of Business Ethics. 6, (8), 633-635.

Oakland, (1993). Total quality management: The route to improving performance, Oxford: Butterworth-Hainemann.

Petrick, J., \& Quinn, J. (1997). Management ethics: integrity at work. Thousand Oaks, CA: Sage.
Sashkin, M., \& Kiser, K. J. (1993). Total quality management. San Francisco: BerettKoehler.

Sashkin, M., \& Richard L. W. (1990). Does fairness make difference? Organizational Dynamic, 1, 56-71.

Schneir, C. E. (1977). Multiple rater groups and performance appraisal. Public Personnel Management, 6, (1), 13-2.

Scholtes, P. R. (1987). An elaboration on derming's teachings on performance appraisal. In Gary McLean, Susan Damme, \& Richard Swanson, Eds., Performance appraisal: perspectives on a quality management approach.

Alexandria, VA: ASTD, and Univ. of Minnesota, 24-52.

Sheppard, B. H., Lewicki, R. J., \& Minton, J. W. (1992). Organizational justice -the search for workplace. New York: Lexington.

Solomon, R. L. (1949). An extension of control group design. Psychology Bulletin, 46, 137-150.

Stephen, G., \& Weimerskirch, A. (1998). Total quality management: strategies and techniques proven at today's most successful companies. $2^{\text {nd }}$ New York: Wiley.

Tolchinsky, P. D., \& Donald, C. K. (1980). Do goals meditate the effects of incentives on performance? Academy of Management Review. 5, 455-467.

Walton, M. (1990). The deming management method. New York: Putnam 